\title{
Direct neural transmission of vCJD/BSE in macaque after finger incision
}

\author{
Jacqueline Mikol $^{1} \cdot$ Jérôme Delmotte $^{1}$ • Dolorès Jouy ${ }^{1}$. Elodie Vaysset ${ }^{1} \cdot$ Charmaine Bastian $^{1} \cdot$ Jean-Philippe Deslys ${ }^{1}$. \\ Emmanuel Comoy ${ }^{1}$ (1)
}

Received: 10 July 2020 / Revised: 8 September 2020 / Accepted: 25 September 2020 / Published online: 6 October 2020

(c) The Author(s) 2020

Non-human primates appeared as the closest model to study human iatrogenic prion diseases [14]: we report here the consequences of variant Creutzfeldt-Jakob disease/bovine spongiform encephalopathy ( $\mathrm{vCJD} / \mathrm{BSE}$ ) inoculation in a cynomolgus macaque finger, with the demonstration of an original mode of propagation and the practical risk for professional exposure.

The distal right middle finger handpad of a 4-year-old macaque was incised on both lateral sides to induce local inflammation, and then injected with the equivalent of $10 \mathrm{mg}$ of a BSE, orally challenged macaque brain [18]. After an 18 months period of finger clumsiness, the clinical disease (behaviour abnormalities, fear, hyperesthesia, gait disturbances, shaking) began 7.5 years after inoculation and euthanasia took place 2 months later for welfare reasons. Motor conduction velocity of the right median nerve was reduced to one-third of the left counterpart and sensory potential was not detected.

Histological and biochemical studies were performed as previously described. All the elements of the triad were present [7-9]: spongiform change was moderate in neocortex, striatum, brain stem, mild in spinal cord but severe in thalamus and cerebellum; neuronal loss was globally moderate, but severe in cerebellum and sacral spinal cord (vacuolated neurons); gliosis was severe in thalamus, cerebellum and brain stem and moderate elsewhere (Supplementary Fig. 1). ELISA and western blot (WB) showed the expected

Electronic supplementary material The online version of this article (https://doi.org/10.1007/s00401-020-02231-w) contains supplementary material, which is available to authorized users.

Emmanuel Comoy

emmanuel.comoy@cea.fr

1 Université Paris-Saclay, CEA, Service d'Etude des Prions et des Infections Atypiques, 18 Route du Panorama, 92265 Fontenay-aux-Roses, France accumulation of $\operatorname{PrP}^{\mathrm{res}}$ with BSE glycophoretic pattern at all levels of brain and spinal cord (Supplementary Fig. 2).

In the brain, $\operatorname{PrP}^{\mathrm{d}}$ deposits were laminar into the cortical deep layers, massive into thalamus, basal ganglia, cerebellum, and brain stem. In spinal cord, $\operatorname{PrP}^{\mathrm{d}}$ was symmetrically distributed, intense in the Substantia gelatinosa and nucleus dorsal of Clarke while decreased at sacral level. Deposits were diverse into the whole CNS: synaptic, perineuronal, reticular aggregates, mini-plaques, plaques, and incomplete florid plaques. The retinal plexiform layers were labelled (Supplementary Fig. 1i). There were no amyloid or tau deposits.

Unusual $\operatorname{PrP}^{\mathrm{d}}$ deposits were observed along dendrites, short and long axons, neuritic threads tracing fine networks of straight lines or like strings of pearls (Supplementary Fig. 3). They were present into deep neocortex, basal ganglia, and motoneurons. Such long processes are not frequent but have been reported in human [13] and experimental studies $[10,22] . \operatorname{PrP}^{\mathrm{d}}$ deposits were also noted as very mild into striato-pallidal projections, both limbs of internal capsule and fornix (Supplementary Fig. 3). The presence of $\operatorname{PrP}^{\mathrm{d}}$ in white matter has been reported (Supplementary text 4).

Peripherally, the expected $\operatorname{PrP}^{\mathrm{d}}$ was undetectable in lymphoid organs, including spleen, through biochemical or immunohistochemical analyses, while prion replication was detected in the peripheral nervous system (PNS): $\operatorname{PrP}^{\mathrm{d}}$ staining was visualized in many dorsal root ganglia (DRG) but only in nerves innervating the forelimb site of injection (median and ulnar nerves). At the cellular level, $\operatorname{PrP}^{\mathrm{d}}$ was limited to ganglia and satellite cells in DRG and Schwann cells (Scs) all along nerves whereas axons were never labelled (Fig. 1). Previously, using postmortem immunohistochemical studies (listed in Supplementary text 5), $\operatorname{PrP}^{\mathrm{d}}$ has been shown in peripheral nervous system in all forms of human neuropathies, albeit more frequently in vCJD, mostly in posterior root nerve fibres at adaxonal location and/or in ganglion and satellite cells. The restricted amount 


\section{Direct neural transmission of $\checkmark C J D / B S E$ in macaque after finger incision}
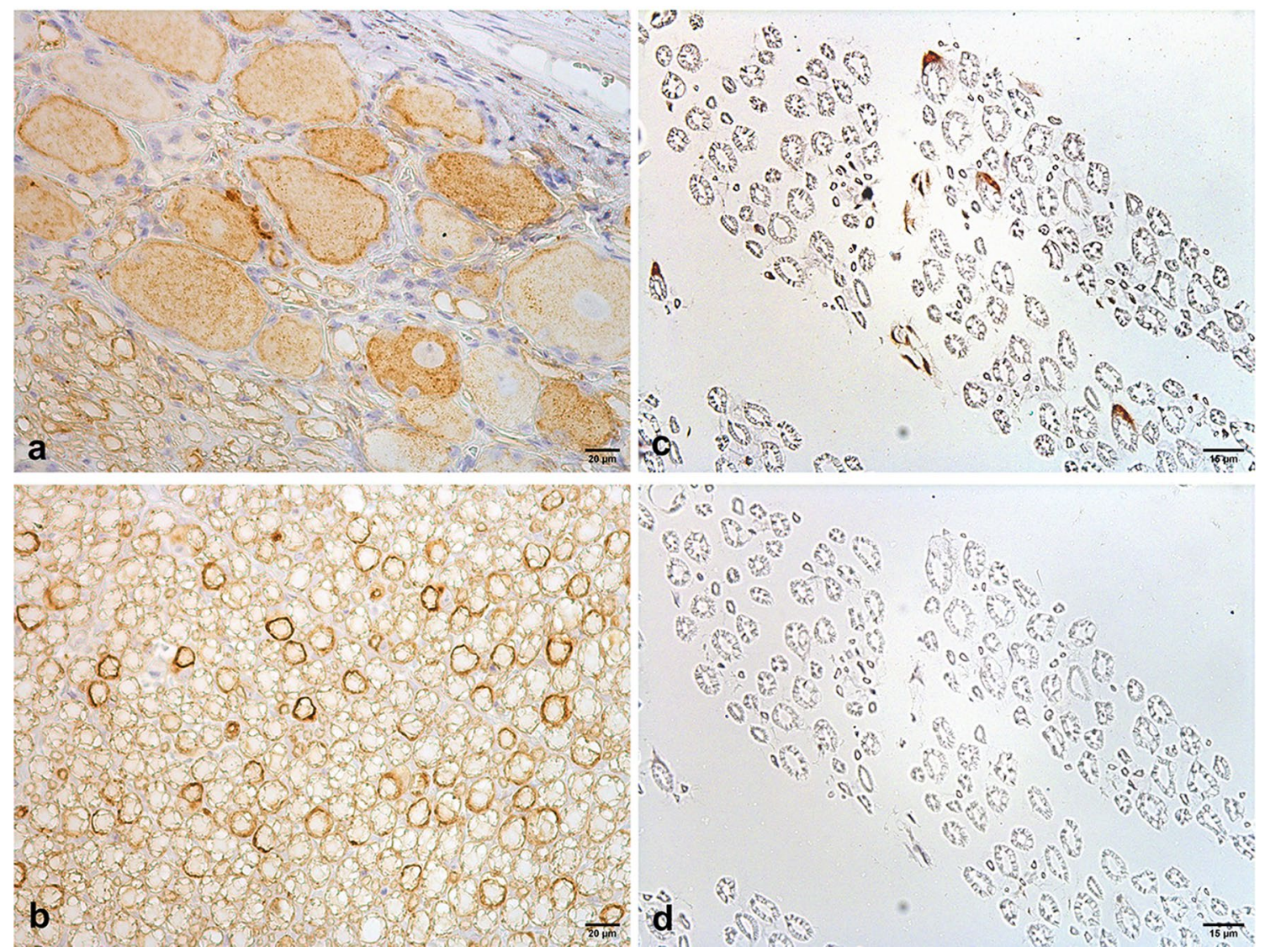

Fig. $1 \operatorname{PrP}^{\mathrm{d}}$ immunostaining (SHA31) of lumbar root ganglia (a) (cytoplasmic dots in ganglia cells and larger aggregates in satellite cells) and lumbar proximal root (b) (adaxonal, but not axonal label-

of $\operatorname{PrP}^{\mathrm{d}}$ was repeatedly underlined but, recently, prion RTQuiC was positive in all nerves examined [2]. $\operatorname{PrP}^{\mathrm{d}}$ has also been described, first in scrapie [17] then in BSE, as limited "adaxonal deposits" or/and Sc deposits, with or without DRG cell involvement (review in [4] and Supplementary text 6). Previous studies of the mode of propagation of $\operatorname{PrP}^{\mathrm{d}}$ have reported variable observations and analyses depending on strains, host species and genotype (Supplementary text 6 ); the authors discussed the role of the sensory route of trafficking of prions, the modifications of axonal transport, the centrifugal versus centripetal spread of $\operatorname{PrP}^{\mathrm{d}}$.

After peripheral infection, accumulation of infectious agent is reputed to occur in lymphoid tissues before direct neuroinvasion $[18,19]$, even with very little apparent peripheral lymphoreticular deposition $[6,20]$. Here, there is no apparent replication/amplification of ${ }^{\mathrm{vCJD}} \mathrm{BSE}$ agent in the lymphoid tissues of the exposed macaque. In this model, the neural contamination occurred directly in the highly innervated finger while neuroinvasion appears ling). $\operatorname{PrP}^{\mathrm{d}}$ immunostaining (3F4) of right proximal median nerve showing a few labelled Schwann cells (c). Isotype control (d)

to occur in Scs along the median nerve to the DRG, with the appearance of the classical labelling of ganglion cells which indicates the onset of the first level of neuronal infection. This model provides direct evidence of the hypothesis of a sequential infection of Scs from the periphery to the CNS, followed by a secondary diffusion into the spinal cord, as already considered by our group [15] and others [1, 3, 11, 12, 21]. It is to note that studies based on intra-sciatic nerve injections in hamsters [16] and transgenic mice [12] had established a rate of transport of infectivity of, respectively, $0.5-2 \mathrm{~mm}$ and $0.7 \mathrm{~mm}$ per day. This key role of Scs could explain both the low speed of propagation and the discrepancy between the paucity of $\operatorname{PrP}^{\mathrm{d}}$ into the distal part of the sensory nerves followed by the positivity of DRG, satellite cells and proximal roots.

In conclusion, we have observed that the exposure of a primate to $\mathrm{VCJD} / \mathrm{BSE}$ through a distal finger lesion induces, after more than 7.5 years of silent incubation, a 
massive deposit of $\operatorname{PrP}^{\mathrm{d}}$, strictly restricted to the nervous system and the eye.

Our data suggest a new type of pure unique peripheral nervous contamination in which the Scs would have a major role in the mode of centripetal progression of $\mathrm{PrP}^{\mathrm{d}}$ in the peripheral nervous system. Moreover, considering the fact that, recently, "a variant CJD diagnosed 7.5 years after occupational exposure" (cryomicrotomy) in a technician was observed [5], this experimental case report supports the risk linked to professional exposure and reinforces the necessity of adequate measures of prevention.

Funding This work has been partly funded by Agence Nationale pour la Recherche (ANR-15-CE18-0028-01).

\section{Compliance with ethical standards}

Ethical approval The experiments performed and described in this article comply with the current laws in Europe and France. The present experiment has been reviewed by the CETEA ethical committee (approval 12-072/17-091/20-042). Non-human primates were housed and handled in accordance with the European Directive 2010/63 related to animal protection and welfare in research, and were under constant internal surveillance by veterinarians. Social enrichment was a constant priority with individual activities and feeding controlled according to the risk of infection. Animals were handled under anaesthesia to limit stress, and euthanasia was performed for ethical reasons when animals lost autonomy.

Open Access This article is licensed under a Creative Commons Attribution 4.0 International License, which permits use, sharing, adaptation, distribution and reproduction in any medium or format, as long as you give appropriate credit to the original author(s) and the source, provide a link to the Creative Commons licence, and indicate if changes were made. The images or other third party material in this article are included in the article's Creative Commons licence, unless indicated otherwise in a credit line to the material. If material is not included in the article's Creative Commons licence and your intended use is not permitted by statutory regulation or exceeds the permitted use, you will need to obtain permission directly from the copyright holder. To view a copy of this licence, visit http://creativecommons.org/licenses/by/4.0/.

\section{References}

1. Archer F, Bachelin C, Andreoletti O, Besnard N, Perrot G, Langevin C et al (2004) Cultured peripheral neuroglial cells are highly permissive to sheep prion infection. J Virol 78:482-490. https:// doi.org/10.1128/JVI.78.1.482-490.2004

2. Baiardi S, Redaelli V, Ripellino P, Rossi M, Franceschini A, Moggio $\mathrm{M}$ et al (2019) Prion-related peripheral neuropathy in sporadic Creutzfeldt-Jakob disease. J Neurol Neurosurg Psychiatry 90:424-427. https://doi.org/10.1136/jnnp-2018-319221

3. Balkema-Buschmann A, Priemer G, Ulrich R, Strobelt R, Hills B, Groschup MH (2019) Deciphering the BSE-type specific cell and tissue tropisms of atypical ( $\mathrm{H}$ and $\mathrm{L}$ ) and classical BSE. Prion 13:160-172. https://doi.org/10.1080/19336896.2019.1651180
4. Beekes M, McBride PA (2007) The spread of prions through the body in naturally acquired transmissible spongiform encephalopathies. FEBS J 274:588-605. https://doi.org/10.111 1/j.1742-4658.2007.05631.x

5. Brandel JP, Bustuchina-Vlaicu M, Culeux A, Belondrade M, Bougard D, Grznarova K et al (2020) variant Creutzfeldt-Jakob disease diagnosed 7.5 years after occupational exposure. N Engl J Med 383:83-85. https://doi.org/10.1056/NEJMc2000687

6. Brandel JP, Heath CA, Head MW, Levavasseur E, Knight R, Laplanche JL et al (2009) Variant Creutzfeldt-Jakob disease in France and the United Kingdom: evidence for the same agent strain. Ann Neurol 65:249-256. https://doi.org/10.1002/ana.21583

7. Comoy EE, Casalone C, Lescoutra-Etchegaray N, Zanusso G, Freire S, Marce D et al (2008) Atypical BSE (BASE) transmitted from asymptomatic aging cattle to a primate. PLoS ONE 3:e3017. https://doi.org/10.1371/journal.pone.0003017

8. Comoy EE, Mikol J, Jaffré N, Lebon V, Levavasseur E, Streichenberger $\mathrm{N}$ et al (2017) Experimental transfusion of variant CJDinfected blood reveals previously uncharacterised prion disorder in mice and macaque. Nat Commun 8:1268. https://doi.org/10.1038/ s41467-017-01347-0

9. Comoy EE, Mikol J, Luccantoni-Freire S, Correia E, LescoutraEtchegaray N, Durand V et al (2015) Transmission of scrapie prions to primate after an extended silent incubation period. Sci Rep 5:11573. https://doi.org/10.1038/srep11573

10. Debeer S, Baron T, Bencsik A (2003) Neuropathological characterisation of French bovine spongiform encephalopathy cases. Histochem Cell Biol 120:513-521. https://doi.org/10.1007/s0041 8-003-0593-5

11. Follet J, Lemaire-Vieille C, Blanquet-Grossard F, Podevin-Dimster V, Lehmann S, Chauvin J-P et al (2002) PrP expression and replication by schwann cells: implications in prion spreading. $\mathrm{J}$ Virol 76:2434-2439

12. Glatzel M, Aguzzi A (2000) PrPC expression in the peripheral nervous system is a determinant of prion neuroinvasion. J Gen Virol 81:2813-2821. https://doi. org/10.1099/0022-1317-81-11-2813

13. Goodbrand IA, Ironside JW, Nicolson D, Bell JE (1995) Prion protein accumulation in the spinal cords of patients with sporadic and growth hormone associated Creutzfeldt-Jakob disease. Neurosci Lett 183:127-130. https://doi.org/10.1016/0304-3940(94)11131 $-2$

14. Herzog C, Riviere J, Lescoutra-Etchegaray N, Charbonnier A, Leblanc V, Sales N et al (2005) PrPTSE distribution in a primate model of variant, sporadic, and iatrogenic CreutzfeldtJakob disease. J Virol 79:14339-14345. https://doi.org/10.1128/ JVI.79.22.14339-14345.2005

15. Herzog C, Sales N, Etchegaray N, Charbonnier A, Freire S, Dormont D et al (2004) Tissue distribution of bovine spongiform encephalopathy agent in primates after intravenous or oral infection. Lancet 363:422-428. https://doi.org/10.1016/S0140 $-6736(04) 15487-1$

16. Kimberlin RH, Hall SM, Walker CA (1983) Pathogenesis of mouse scrapie: evidence for direct neural spread of infection to the CNS after injection of sciatic nerve. J Neurol Sci 61:315-325. https://doi.org/10.1016/0022-510X(83)90165-X

17. Kimberlin RH, Walker CA (1980) Pathogenesis of mouse scrapie: evidence for neural spread of infection to the CNS. J Gen Virol 51:183-187. https://doi.org/10.1099/0022-1317-51-1-183

18. Lasmezas CI, Comoy E, Hawkins S, Herzog C, Mouthon F, Konold $\mathrm{T}$ et al (2005) Risk of oral infection with bovine spongiform encephalopathy agent in primates. Lancet 365:781-783. https://doi.org/10.1016/S0140-6736(05)17985-9

19. Mabbott NA, Alibhai JD, Manson J (2018) Chapter 5-the role of the immune system in prion infection. In: Pocchiari M, Manson 
J (eds) Handbook of clinical neurology. Elsevier, New York, pp 85-107

20. Mead S, Wadsworth JD, Porter MC, Linehan JM, Pietkiewicz W, Jackson GS et al (2014) Variant Creutzfeldt-Jakob disease with extremely low lymphoreticular deposition of prion protein. JAMA Neurol 71:4. https://doi.org/10.1001/jamaneurol.2013.5378

21. Okada H, Iwamaru Y, Yokoyama T, Mohri S (2013) Immunohistochemical detection of disease-associated prion protein in the peripheral nervous system in experimental H-type bovine spongiform encephalopathy. Vet Pathol 50:659-663. https://doi. org/10.1177/0300985812471541
22. Wells GA, Scott AC, Johnson CT, Gunning RF, Hancock RD, Jeffrey $\mathrm{M}$ et al (1987) A novel progressive spongiform encephalopathy in cattle. Vet Rec 121:419-420. https://doi.org/10.1136/ vr.121.18.419

Publisher's Note Springer Nature remains neutral with regard to jurisdictional claims in published maps and institutional affiliations. 